\title{
STRUCTURAL ANALYSIS OF A TROPICAL FOREST ECOSYSTEM
}

\section{ANÁLISE ESTRUTURAL DE UM ECOSSISTEMA FLORESTAL TROPICAL}

\author{
Gustavo Aveiro Lins \\ CEDERJ/SEE-RJ/CEDAE \\ Elizabeth dos Santos Rios \\ Observatório Urbano/UERJ/UN-Habitat/CRBIO-02 \\ André Luiz Nascimento Parcial \\ Observatório Urbano/UERJ/UN-Habitat \\ Manoel Gonçalves Rodrigues \\ Observatório Urbano/UERJ/UN-Habitat \\ Josimar Ribeiro de Almeida \\ Observatório Urbano/UERJ/UN-Habitat
}

\begin{abstract}
The forest studied is highly heterogeneous. This heterogeneity grow as increase the size of the vegetation cover, because for the level I approach was found average value of 1:14, 1:10, 1:13 and 1:9 for the Jentsch Quocient index, respectively, for the total population, population without liana, population without palm tree and population without liana and palm tree, increasing these values in the level II to $1: 3$ and level III to I:2. The same value at the quocient index in the level II and III, for the four fraction of the population due the fact in this level the presence of liana and palm tree is insignificant in relation to the total number of individuals. However, in the level I, the removal increases the quociente index and so, the forest heterogeneity of this population.
\end{abstract}

Keywords: Forest Ecosystem, Plant heterogeneity and Population.

\section{RESUMO}

A floresta estudada é altamente heterogênea, com essa heterogeneidade aumentando à medida que aumenta 0 tamanho da cobertura vegetal pois para o nível I de abordagem encontraram-se valores médios de 1:14, 1:10, 1:13 e 1:9 para o quociente de mistura de Jentsch, respectivamente para a população total, população sem cipós, população sem palmeiras e população sem cipós e palmeiras, aumentando esses valores no nível II para 1:3 e nível III para I :2. O valor igual do quociente de mistura nos níveis II e III, para as quatro frações do povoamento deve-se ao fato de que nesses níveis a presença de cipós e palmeiras é insignificante em relação ao total de indivíduos. Entretanto, no nível I, a retirada aumenta o quociente de mistura e portanto a heterogeneidade florística dessa fração do povoamento.

Palavras-chave: Ecossistema florestal, Heterogeneidade vegetal e População. 


\section{INTRODUÇÃO}

The method of structural analysis of a forest based on quantitative elements, or analytical method searches ranking of species according to their importance within the forest ecosystem. For this are calculated separately the various structural parameters such as quociente index, degree of homogeneity, abundance, dominance, frequency, sociological position and natural regeneration.

Excepting the first two, the other parameters are calculated in a relative way, providing as Curtis et al. (1951. 1956. 1959), Lamprecht (1964), Veja (1968), Finol (1971), Longhi (1980), e Carvalho (1982), the raking of species within the horizontal structure of the forest through the "Importance Value Index" (IVI), which is the sum of the abundance parameters, dominance and frequency. The parameters sociological position and natural regeneration, according Finol (1971) constitute the vertical structure, without which it would not be the perfect characterization of the order of ecologically important species. The introduction of the vertical structure has expanded the "IVI" came to be called "Importance Value Index Expanded" (IVIA).

The quociente index parameters and degree of homogeneity, though they are not included in calculating the IVI or IVIA, because they reflect characteristics of the ecosystem and not the species, it should be evaluated in the structural analysis, as they represent futher information in making decisions the management.

The structural analysis in order to assist in the preparation of management plans can not ignore the structural evaluation that, according Finol (1964), although a difficult task to interpret, it is interesting to study it and clarify its phytosociological significance in the development of forest until the climax.

\section{MATERIAL E MÉTODOS}

To evaluation the sampling Husch et al. (1972) mention within the random processes, the process of sampling in two stages, that is a limited random process, where the second stage of sampling is restricted or dependent on the first stage. Its main advantage is the reduction of costs resulting from the concentration of subsampling within primary units. In this process, the primary and secondary sampling units are pre-defined in shape and size. Higuchi 
et al, (1982) tested several sizes of sample plots, concluding that the rectangular plots show better results than the square ones and can be used in general installments of up to $40 \mathrm{~m}$ wide by $150 \mathrm{~m}$ long. For Lamprecht (1964) the sample size for structural studies should be not less than 1 hectare, varying the shape, however recommended to use samples from $20 \mathrm{~m}$ to $500 \mathrm{~m}$ as standard. Samples of smaller units will not have the same efficacy in tropical forests.

The target population of this study consists of vegetation cover compounded by individuals with total height (h) greater than or equal to $10 \mathrm{~cm}$, which implies a large amplitude distribution. The sample was divided into three levels of approach. depending on the size of individuals, thus there are: Level I - To approach individuals with greater than or equal to $10 \mathrm{~cm} \mathrm{DBH}$ less than $5 \mathrm{~cm}$ total height; Level II - To approach individuals with DBH or equal to $5 \mathrm{~cm}$ and less than $20 \mathrm{~cm}$; Level III - to approach individuals with DBH greater than or equal to $20 \mathrm{~cm}$.

For Level I approach, it was used bands $2 \mathrm{~m}$ wide and 100 long, which are the primary units, divided into plots of $2 \mathrm{~m} 10 \mathrm{~m}$ (secondary units), which in turn were divided into square plots of $2 \mathrm{~m}$ side. Sample units used in Level II consisted of bands from $10 \mathrm{~m}$ wide and $100 \mathrm{~m}$ long (secondary units) located in the middle of the unit of $20 \mathrm{~m}$ by $500 \mathrm{~m}$ level III (primary drive) and divided into square plots $10 \mathrm{~m}$ side. The shape and size of the sample units level III have previously been established, based on the shape and size proposed by Lamprecht (1964) and Finol (1971). Thus, bands of 1 hectare, $20 \mathrm{~m}$ wide and $500 \mathrm{~m}$ long, divided into plots of $20 \mathrm{~m}$ by $100 \mathrm{~m}$, and these in subplots of $10 \mathrm{~m} \times 20 \mathrm{~m}$.

The sampling system adopted in data collection was mixed, systematic - random, in which sample units level III were systematically distributed according to the axes North South and East - West. The secondary sample units level II were randomly drawn and distributed within the sample units of Level III and Level I secondary units were randomly selected and randomly distributed within the secondary level II units, thus characterizing the sampling process in two stages described by Husch et al. (1972). The preliminary sampling consisted of measuring 8 units at the Level III, 24 secondary units at Level II and 120 secondary units at Level I. From the data collected in this preliminary sampling, the optimal sampling intensity was calculated to approach quantitatively the population. The suitable approach qualitatively, ie, to approach the floristic composition of settlement intensity was obtained by species area curve Oosting (1951).

Dosting (1951) states that, for the taking of samples, a rectangular plot is markedly 
more effective than a square of equal area because it tends to include a better representation of the variation in the community, and to circumvent this problem has used the species - area curves. Coordinate axes in plotting the number of species obtained as a function of sample area, we obtain an asymptotic curve, characteristic for each community. Cain et al. (1959) conclude that sampling is appropriate when a $10 \%$ increase in sample surface implies a $10 \%$ increase in number of species. This point of the curve is determined by the tangent to the curve, and parallel to the line passing through the intersection of the coordinate axes and the point whose coordinates are $10 \%$ of the total area and $10 \%$ of the total species. The point of tangency determines the minimum sample size.

\section{RESULTS AND DISCUSSION}

Table I shows the average values of the Jentsch Quocient index approach in each level and for each fraction of the population, ie, total population, population without lianas, population without palms trees, population without lianas and palms trees.

Table 1 - Jentsch Quocient index.

\begin{tabular}{|c|c|c|c|c|c|c|c|c|c|c|}
\hline $\begin{array}{c}\text { Level of } \\
\text { Approach }\end{array}$ & \multicolumn{3}{|c|}{ I } & \multicolumn{3}{c|}{ II } & \multicolumn{3}{c|}{ III } & \\
\hline Population & Species & individuals & QM & Species & individuals & QM & Species & individuals & QM & $\overline{Q M}$ \\
\hline TOTAL & 141,958 & 1653,227 & $1: 14$ & 103,851 & 308,938 & $1: 3$ & 91,376 & 209,753 & $1: 2$ & $1: 8$ \\
$\begin{array}{c}\text { without } \\
\text { lianas }\end{array}$ & 140,756 & 1039,178 & $1: 10$ & 102,961 & 298,129 & $1: 3$ & 91,378 & 209,754 & $1: 2$ & $1: 6$ \\
$\begin{array}{c}\text { without } \\
\text { palms tree }\end{array}$ & 140,451 & 1481,729 & $1: 13$ & 102,470 & 305,376 & $1: 3$ & 91,127 & 205,376 & $1: 2$ & $1: 6$ \\
$\begin{array}{c}\text { without } \\
\text { lianas and } \\
\text { palms trees }\end{array}$ & 139,865 & 1858,923 & $1: 9$ & 101,468 & 296,876 & $1: 3$ & 91,127 & 205,378 & $1: 2$ & $1: 5$ \\
\hline
\end{tabular}

As can be seen in the table, the forest studied is highly heterogeneous, with this heterogeneity as increase the size of the vegetation cover, because for level I approach was found the average values of 1: 14, 1:10, 1: 13 and for the 1:9 Jentsch Quocient index, respectively for the total population, population without liana, population without palm trees and vines and palm population without increasing these values at level II and level III to 1:3 to 
1:2. The same value of the quocient index in the level II and III, for the four fractions of the population due to the fact that at these levels the presence of liana and palm trees is insignificant compared to the total number of individuals. However, at level I, the removal increases the quociente index and thus the floristic heterogeneity of this fraction of the population.

The greater heterogeneity of the adult population can be explained by the smaller number of individuals as a result of competition for space. The number of species, although slightly lower levels I and II, it is still very high, which also contributes to fuel quociente index. The forest studied presents average values of 1:8, 1:6, 1:7 and 1:5 for the quociente index, respectively, for the total population, without palm trees and without lianas and palms.

The great majority of the species occur in the frequency class I (0-20\%), with $61.05 \%$, $91.65 \%$ and $57.09 \%$, respectively for the levels of approach I, II and III, the average percentage of number of species in this class. These values indicate that the species has a very irregular spatial distribution within the structure of the forest, especially at level II, where only one morphospecies showed a absolute frequency average greater than $60 \%$. This irregularity spatial distribution of species highlights the floristic heterogeneity that exists within each sample.

As can be seen in the table, three approach levels have very low values of the degree of homogeneity, particularly with a level II - 4.58, and - 3.38 of the average degree of homogeneity of the forest studied.

Table 2 - degree of homogeneity of the forest

\begin{tabular}{|c|c|c|c|c|c|c|c|c|c|c|c|c|c|}
\hline \multirow[t]{2}{*}{ Sample } & \multicolumn{4}{|c|}{ Level I } & \multicolumn{4}{|c|}{ Level II } & \multicolumn{4}{|c|}{ Level III } & \multirow{2}{*}{$H$} \\
\hline & $\overline{\sum_{x}}$ & $\sum_{y}$ & $\sum_{n}$ & $H$ & $\sum_{x}$ & $\sum_{y}$ & $\sum_{n}$ & $H$ & $\sum x$ & $\sum_{y}$ & $\sum_{n}$ & $H$ & \\
\hline 1 & 8 & 103 & 158 & $-3,01$ & & 106 & 112 & $-4,73$ & & 71 & 107 & $-3,32$ & $-3,69$ \\
\hline 2 & 6 & 88 & 144 & $-2,85$ & & 124 & 113 & $-4,66$ & 1 & 50 & 93 & $-2,63$ & $-3,38$ \\
\hline 3 & 5 & 92 & 148 & $-2,94$ & & 95 & 106 & $-4,48$ & 3 & 56 & 95 & $-2,79$ & $-3,40$ \\
\hline 4 & 6 & 81 & 140 & $-2,68$ & & 98 & 111 & $-4,41$ & 5 & 54 & 99 & $-2,47$ & $-3,19$ \\
\hline 5 & 4 & 99 & 145 & $-3,28$ & & 101 & 110 & $-4,59$ & 1 & 56 & 100 & $-2,75$ & $-3,54$ \\
\hline 6 & 9 & 89 & 160 & $-2,50$ & & 80 & 88 & $-4,55$ & 5 & 57 & 102 & $-2,55$ & $-3,20$ \\
\hline 7 & 7 & 98 & 154 & $-2,95$ & & 122 & 130 & $-4,69$ & 2 & 65 & 118 & $-2,67$ & $-3,44$ \\
\hline 8 & 7 & 91 & 165 & $-2,55$ & & 108 & 120 & $-4,50$ & 3 & 54 & 97 & $-2,63$ & $-3,23$ \\
\hline Average & 6.500 & 92.625 & 151.750 & $-2,85$ & & 104,750 & 113.750 & $-4,58$ & 2.500 & 57.875 & 101.375 & $-2,73$ & $-3,38$ \\
\hline
\end{tabular}

From the qualitative point of view, ie, in relation to the floristic composition population, it can be seen that the species-area curves described by the model $y=a+b \ln x$, for each 
sample and the total sample at each level approach, showed a high degree of fit, with values of " $r$ " not less than 0.89 .

When analyzing the equations, it is observed that " $\rho "$ ", which represents the point on the curve where an increase of $10 \%$ in the sample area implies a $10 \%$ increase in the number of species and, according to Cain et al. (1959), indicates the minimum sample size, determines values of " $\mathrm{x}$ ", ie, the number of plots of $2 \mathrm{~m} \times 10 \mathrm{~m}$, ranging 3-5 parcels for basic samples $(20 \mathrm{mx} 500 \mathrm{~m})$ isolated. It is also observed that the curves do not show a clear trend of asymptotic stabilization, which highlights the floristic heterogeneity of this fraction of the forest; although the overall curve samples present a higher asymptotic trend, which demonstrates the sampling scope.

Species / area curve of level I (DBH more than or equal to $10 \mathrm{~cm}$ and less than $5 \mathrm{~cm}$ ), $\mathrm{N}=50.76+47.61$ with $\mathrm{r} 2=0.99$ adjusted by $\mathrm{Y}=\mathrm{a}+\mathrm{b} \ln \mathrm{X}$ where $\mathrm{Y}=$ number of model species (N) and $X=$ the number of plots $2 \times 10 \mathrm{~cm}$.

Species / area curve of level II (DBH more than or equal to $5 \mathrm{~cm}$ and less than $20 \mathrm{~cm}$ ), $\mathrm{N}=-66.44+55.78$ with $\mathrm{r} 2=0.98$ adjusted by $\mathrm{Y}=\mathrm{a}+\mathrm{b} \ln \mathrm{X}$, where $\mathrm{Y}=$ number of model species and $X=$ number of plots of $10 \mathrm{~m} \times 10 \mathrm{~m}$.

Species / area curve of level III (DBH more than or equal to $10 \mathrm{~cm}$ ), $\mathrm{N}=97.53+52.72$ with $\mathrm{r} 2=0.95$ adjusted for model $Y=a+b \ln X$, where $Y=$ number of species and $X=$ number of plots of $10 \mathrm{~m} \times 20 \mathrm{~m}$.

\section{BIBLIOGRAPHY}

Cain. S. A. \& Castro, G. M. de Oliveira - 1959. Manual of vegetation analysis. Hafner Publishing Company. N. York. 325 p.

Cain, S. A.; Castro, G. M. de Oliveira; Pires, J. M.; Silva, N. T. da - 1956. Application of some phytosociological tecniques to Brazilian rain forest. Amer. Journ. Of Botany, 43 (10): 911 - 941.

Carvalho, J. O. P. - 1982. Análise estrutural da regeneração natural em floresta tropical densa na Região do Tapajós no Estado do Pará. Curitiba. Tese de Mestrado. UFPr. 63 p.

Finol, U. H. - 1971. Nuevos parametros a considerarse en el analisis estrutural de las selvas virgenes tropicales. Ver. For. Venez., 14 (21): 29-42.

Higuchi, N.; Santos, J. dos; Jardim, F. C. da S. - 1982. Tamanho de parcelas amostrais 
para inventários florestais. Acta Amazônica, 12 (I): 91-103.

Husch, B.; Miller, C. I.; Beers, T. W. - 1972 - Forest mensuration. The Ronald press. 410 p. Lamprecht, H. - 1964. Ensayo sobre la estrutura florística de la parte sur-oriental del Bosque Universitário "El caimital", Estado Barinas. Rev. Form. Venez. 7 (10-11): 77-119.

Loetsch, F.; Zohrer, F.; Haller, K. E. - 1973. Forest inventory. Wien Munchen, BLV. Verlagsgesellschft. V.2. $469 \mathrm{p}$.

Longhi, S. J. - 1980. A estrutura de uma floresta natural de Araucaria angustifólia (Bert.). O. Ktze, sul do Brasil. Curitiba. Disserttação de Mestrado. UFPr. 198 p.

Veja, C. I. - 1968. La estructura y composicion de los bosques humedos tropicales del Carare, Colombia. Turrialba, 18 (4): 416-436.

Recebido: 05/03/2014 Aprovado: 15/06/2014 